\title{
GLOBALISASI: ANTARA PELUANG DAN ANCAMAN BAGI MASYARAKAT MULTIKULTURAL INDONESIA
}

\section{Umar Sholahudin}

Program Studi Sosiologi Universitas Wijaya Kusuma Surabaya

Email : umar.sholahudin@gmail.com

\begin{abstract}
Abstrak
Artikel ini mengkaji tentang globalisasi, antara peluang dan ancaman bagi masyarakat multikultural Indonesia. Globalisasi telah membawa perubahan kehidupan sosial, politik, ekonomi, dan budaya masyarakat, khususnya bagi masyarakat Indonesia yang multikultural. Arus deras globalisasi yang terus bergerak menerobos berbagai lini kehidupan masyarakat dan mereduksi batas wilayah bangsa-negara. Globalisasi akan membawa dua konsekwensi sekaligus bagi masyarakat kultiultural Indonesia, yakni bagaimana peluang dan ancaman globalsiasi terhadap masyarakat multikultural Indonesia. Studi ini menggunakan pendekatan studi kepustakaan, dimana data dan informsai yang relevan dengan topik atau masalah yang menjadi objek kajian dan dihimpun dari berbagai sumber ilmiah dan sumber-sumber lain. Kerangka teoiritis yang digunakan dalam studi ini adalah teori homogenisasi budaya. Hasil dari kajian kepusatakan ini, menunjukkan bahwa arus globalisasi akan memberi ancaman sekaligus peluang bagi masyarakat multikultural Indonesia. Peluang yang dapat dimanfaatkan adalah munculnya kesadaran kolektif tentang hidup bersama dalam perbedaaan yang bersifat koeksistensi. Sementara itu, ancaman yang perlu diwaspadai, yakni menguatnya homogenisasi budaya yang dapat menggerus dan mencerabut akar budaya lokal. Karena itu, masyarakat multikultural Indonesia tidak hanya dituntut berfikir dan bertindak lebih kritis dan cerdas dalam menghadapi berbagai dampak subversif dan destruktif dari globalisasi, tetapi lebih dari itu mampu membangun imunitas keberagaman.
\end{abstract}

Kata kunci: globalisasi; peluang; ancaman; masyarakat multikultural; indonesia

\section{GLOBALIZATION: BETWEEN OPPORTUNITIES AND THREATS FOR INDONESIAN MULTICULTURAL COMMUNITIES}

\begin{abstract}
This article examines globalization, between opportunities and threats for Indonesia's multicultural society. Globalization has brought changes in the social, political, economic, and cultural life of the people, especially for multicultural Indonesians. The swift flow of globalization that continues to move through various lines of life of people and reduce the borders of nations. Globalization will bring two consequences at the same time for the Indonesian cultural community, namely how the opportunities and threats of globalization to Indonesia's multicultural society. This study uses a literature study approach, where data and information relevant to the topic or problem are subject to study and compiled from various scientific sources and other sources. The theoritical framework used in this study is the theory of cultural homogenization. The results of this literature study indicate that the current of globalization will pose a threat as well as an opportunity for Indonesia's multicultural society. An opportunity that can be exploited is the emergence of a collective awareness about living together in differences that are co-existent. Meanwhile, the threat that needs to be watched out for is the strengthening of cultural homogenization that can erode and uproot the roots of local culture. Therefore, Indonesian multicultural society is not only required to think and act more critically and intelligently in dealing with the various subversive and destructive effects of globalization, but more than that it is able to build diversity immunity.
\end{abstract}

Keywords: globalization; opportunities; threats; multicultural communities; Indonesia 


\section{LATAR BELAKANG}

Sejumlah ilmuwan telah berusaha membuat definisi tentang globalisasi. Tetapi nampaknya masih agak susah untuk memberikan suatu definisi yang baku. Kesamaan karakteristik yang ada pada setiap definisi adalah kesepakatan untuk mengatakan bahwa globalisasi merupakan proses trasformasi ke arah pengembangan sistem-sistem global dengan target utama adalah sector ekonomi. Pengembangan sistem global memunculka hubungan lintas-batas antar Negara dan saling mempengaruhi sehingga membentuk suatu tatanan nilai baru (Parani, R, 2001)

Menurut Giddens (1990:64) bahwa globalisasi adalah intensifikasi hubungan sosial dunia di mana kejadian di suatu Negara akan saling berpengaruh terhadap Negara lannya. Jadi, globalisasi menuntut suatu negara untuk membuka diri terhadap perkembangan dunia, terutama perkembangan ekonomi, agar dapat bersaing dan saling melengkapi.

.Kata "globalisasi" diambil dari kata global, yang maknanya ialah universal. Globalisasi belum memiliki definisi yang mapan, kecuali sekedar definisi kerja (working definition), sehingga tergantung dari sisi mana orang melihatnya. Ada sebagian memandang perubahan besar yang terjadi sebagai suatu proses sosial, atau proses sejarah, atau proses alamiah yang akan membawa seluruh bangsa dan negara di dunia makin terikat dan bergantung satu sama lain, mewujudkan satu tatanan kehidupan baru atau kesatuan koeksistensi (uniformitas) dengan menyingkirkan batas-batas geografis, ekonomi dan budaya masyarakat yang dianggapnya lebih baik. Namun demikian, sebagian yang lain memandang perubahan besar tersebut tidak sekedar perubahan yang bergerak secara alamiah, namun by design.

Ada idiologi dominan yang menggerakan perubahan besar tersebut, yakni kapitalisme. Perubahan besar ini digambarkan secara detail oleh Karl Polanyi (2003) sebagai transformasi besar yang dikendalikan oleh idologi dominan dunia, yakni kapitalisme. Idiologi ini yang coba disebarluaskan ke berbagai pelosok dunia untuk bisa diterapkan sebagai idiologi tunggal dalam praktek pembangunan suatu negara. Kita hidup di dalam dunia transformasi, yang mempengaruhi hampir setiap aspek dari apa yang kita lakukan. Entah baik atau buruk, kita didorong masuk ke dalam tatanan global yang tidak dipaami sepenuhnya oleh siapapun, tetapi dampaknya dapat dirasakan kita semua. Ini yang disebut oleh A. Giddens sebagai globalisasi (Giddens, 2001: 1).

Secara historis, globalisasi pada awal perkembangannya identik dengan suatu proses pengintegrasian ekonomi nasional bangsabangsa ke dalam sistem ekonomi global. Namun dalam perkembangan lebih lanjut, proses pengintegrasian tersebut tidak hanya sekedar bidang ekonomi semata, namun semakin meluas ke bidang kehidupan masyarakat laiannya, seperti; sosial, politik, dan budaya ke dalam satu sistem dunia. Dalam konteks ini ada upaya universalisasi dan uniformitas dengan menggunakan standar-standart nilai internasional atau global (Faqih, M. 2001).

Di era globalisasi, sekat-sekat dan batasbatas yang sifatnya fisik -seperti wilayah dan geografis- maupun non-fisik- seperti nilai, norma, dan budaya masyarakat semakin hilang dan digantikan dengan satu sistem nilai, norma, dan budaya global. Dampak dari globalisasi budaya tak hanya mengarah pada lembaga, tapi juga menyerang indvidu atau kelompok. Setiap orang atau kelompok -pada kondisi tertentu"dipaksa" untuk menyesuaikan diri dengan pola dan sistem budaya global. Siapapun yang tidak mau berubah, maka ia akan dilindas oleh perubahan itu sendiri.

Kondisi tersebut apa yang digambarkan oleh Futurolog John Naisbit dan Alvin Tofler sebagai gambaran dunia yang semakin sempit. Sebagaimana dikemukakan ahli komunikasi Kanada, McLuhan; dunia bagaikan suatu kampung besar (global village). Dan kehidupan kita tak dapat melepaskan diri dari kehidupan global. Batas-batas teritorial sebuah negara dipahami bukan sekedar batas geografis yang memisahkan sebuah negara dengan negara lain, melainkan batas-batas budaya, yang memisahkan sebuah komunitas budaya yang 
satu dengan yang lain. Mengikuti integrasi sistem ekonomi nasional ke dalam sistem ekonomi global, dalam aspek budayapun akan terjadi hal yang sama. globalisasi menuntut adanya pengintegrasian sistem budaya nasional ke dalam sistem budaya global. Dalam pandangan kaum modernism, globalisasi dan modernisasi akan melahirkan homogenisasi kultural (penyeragaman budaya).

Dalam konteks Indonesia, di bidang politik dan demorkatisasi milsanya, Gerakan mahasiswa 1998 yang begitu massif dan ekspresif di seluruh kota-kota besar telah mamaksa Soeharto yang telah berkuasa 32 tahun lebih lengser. Jatuhnya rezim otoritarianisme di bawah kendali Soeharto ini telah membuka pintu akan lahirnya era demokratisasi, yakni proses menuju demokrasi. Selain karena faktor domestik, arus demokratisasi di Indonesia, tak dapat dilepaskan dengan arus proyek global demokrasi yang dijalankan dan disebarkan Barat ke berbagai negara di dunia dan yang tak dapat dilupakan juga adalah krisis ekonomi juga turut menyumbang kejatuhan rejim Soeharto. Begitu juga di bidang sosial, ekonomi, dan budaya. Ada pola yang sama dan seragam, bagaimana kehidupan sosial, ekonomi, politik, dan budaya masyarakat negara-bangsa, termasuk masyarakat Indonesia di set-up dengan menggunakan satu sistem dunia baru. Dalam konteks ini ada upaya "uniformitas" dengan mengunakan standarstandart nilai internasional.

Para teoritisi, penganjur dan penganut globalisasi percaya dan yakin, bahwa kesejahteraan dan kemakmuran "bersama" akan dapat diwujudkan dengan membuat dan mensepakati tatanan baru dengan standart dan nilai baru di antara negara-negara yang bersifat global. Selain itu, Para globalis positif dan optimistis menanggapi dengan baik perkembangan semacam itu dan menyatakan bahwa globalisasi akan menghasilkan masyarakat dunia yang toleran dan bertanggung jawab. Akan tetapi, Dalam pandangan A. Giddens (2001: 15-25), globalisasi ternyata tidak menjamin kehidupan masyarakat semakin tenang, nyaman dan aman, namun justru melahirkan kegelisahan, serta ditandai dengan jurang pemisah yang dalam. Banyak di antara kita merasa ada di dalam cengkeram kekuatan yang melampaui kemampuan kita. Dengan kata lain, kehidupan kita bagaikan dalam dalam sel penjara; dikungkung dan dikendalikan secara dominan dan hegemonis oleh sebuah kekuatan besar, yakni idiologi dan kekuatan liberalism dan kapitalisme dunia yang direpresentasikan oleh Barat-Amerika.

Para teoritisi globalisasi menyatakan, setiap negara apapun dan dimanapun tak bisa menghindari dan berpaling dari arus globlisasi yang sejartinya dalah lanjutan dari idiologi developmentalisme (idiologi pembangunan) yang mengadopsi teori-teori modernisasi. Paham pembangunan dan teori-teori modernisasi ini yang menjadi bagian dari media dominasi karena teori tersebut direkayasa menjadi paradigma dominan untuk perubahan sosial Dunia Ketiga oleh Negara-negara industry maju. Dengan kata lain, dominasi dan kolonialisasi tidak hanya terjadi secata fisik, melainkan melalui hegemoni yakni dominasi melalui produksi pengetahuan (Faqih, M. 2001).

Pada gambaran lain, globalisasi juga dapat memperkuat identitas kultural, termasuk agama. Menguatnya Identitas Agama (Islam, Kristen, dan sebagainya) ini dimanifestasikan dalam bentuk munculnya gerakan sosialkeagamaan. Gerakan ini merupakan respon atau "counter attack" terhadap dominasi sosial, politik, ekonomi, dan budaya Barat yang membelenggu masyarakat non Barat atau Asia, termasuk Indonesia. Kelompok radikal fundamentalisme agama menilai modernisasi dan westernisai yang terjadi dan berlangsung cukup lama dalam masyarakat Asia (baca: khususnya indonesia) ternyata tidak memberikan perbaikan bagi kehidupan masyarakatnya, justru yang terjadi proses perusakan dan penghilangan nilai dan tradisi lokal yang berjalan secara massif dan sistematis. Dalam konteks Indonesia, munculnya gerakangerakan sosial-keagamanan dalam bentuk aksi unjuk rasa dan solidaritas dunia Islam, yang mengecam tindakan kolonialisme Barat dan Amerika Serikat di negara-negara Islam, seperti 
Palestina, Siria, Iraq, termasuk praktek neokolonialisme sumber daya alam di Indonesia.

Masyarakat Indonesia yang dikenal sebagai masyarakat multukultural. Masyarakat yang terdiri berbagai ragam komunitas dengan latar belakang budaya, baik suku bangsa, agama, etnis, bahasa, adat istiadat dengan segala kelebihannya. Dengan keragaman budaya tersbeut, mereka dapat hidup berdampingan, saling menghirmati dan menghargai perbedaan yang ada. Keragamanan laksana pelangi yang dikelola dan diikat dengan semangat dan nilainilai kebersamaan sehingga menjadi sebuah gambaran yang indah.

Tatanan sosial-budaya dari masyaraat Indonesia yang pluralistik tersebut akan mengahadapi ujian serius dengan munculnya arus globalsiasi yang semakin masif. Dalam konteks ini, bagaimana peluang dan ancaman yang akan dihadapi masyarakat multikultural Indonesia saat ini. Studi ini menggunakan pendekatan studi kepustakaan, dimana data dan informsai yang relevan dengan topik atau masalah yang menjadi objek kajian dan dihimpun dari berbagai sumber ilmiah dan sumber-sumber lain. Kerangka teoritik yang digunakan dalam kajian ini adalah teri homogeniasasi budaya.

\section{METODE PENELITIAN}

Penelitian ini adalah hasil dari studi kepusatakaan (literatur), di mana kegiatan penelitian ini dilakukan untuk menghimpun data informasi yang relevan dengan topik atau masalah yang menjadi objek kajian atau penelitian. Data dan informasi penelitian diperoleh dan dihimpun dari berbagai sumber ilmiah, seperti buku-buku, karya ilmiah baik yang tersedia secara daring maupun luring, dan sumber-sumber lain yang relevan. Dengan melakukan studi kepustakaan, peneliti dapat memanfaatkan semua informasi dan pemikiranpemikiran yang relevan dengan topik penelitian ini. Dari data dan informasi yang relevan tersebut dianalisis secara kualitatif dengan menggunakan kerangka teoritik yang tersedia.
HASIL DAN PEMBAHASAN

Perspektif Homogenisasi Budaya

Secara teoritis, kajian tentang homogensasi budaya merujuk pada teori Homogenisasi Budaya Kevin Robbins. Dalam bukunya Tradition and Translation: National Cultural in i'ts Globlal Context (1991), Robins menyebut tentang teori Homogenenisasi Budaya atau penyeragaan budaya. Teori ini berusaha menjelaskan bagaimana kehidupan tradisi-tradisi masyarakat lokal dalam kehidupan global. Penyeragaman budaya ini sebagai akibat dari virus globalisasi budaya. Virus ini disebarkan ke seluruh penjuru dunia. Budaya global, yang identik dengan budaya Barat bergerak tanpa batas melalui idiologi kapitalisme masuk ke berbagai negara.

Dalam tulisannya tentang Homogenisasi Budaya dan Siasat Hibriditas, Murdianto An Nawe, menjelaskan bahwa globalisasi budaya menurut teori Robins ini adalah homogensasi. Teori ini menyatakan bahwa globalisasi kapitalisme menimbulkan hilangnya keragaman. Hilangnya kergaaman budaya ini diakibatkan karena adanya imperalisme budaya, di mana budaya dominan akan tersebar bersama globalisasi informasi, media massa, dan pada saat yang sama ekspresi-ekspresi yang lebih lokal dan lemah akan perlahan-lahan terhapus dari peta kebudayaan dunia. Idiologi dan praktek kapitalisme pada kenyataannya terkait dengan pembaratan atau sering disebut sebagai "westernisasi", eksport komoditas, nilai, prioritas dan cara hidup ala Barat (Opini Geotimes.co.id, 27 Januari 2018)

Homogenisasi merupakan bahasa lain dari monukulturalalism, yang berusaha untuk melakukan penyeragaman yang berakhir pada penyatuan pada budaya tunggal yang dominan. Praktek ini merupakan lawan dari idiologi multikulturalisme. Dalam konteks ini, ChangYau-Hoon, mengatakan multikulturalisme sengaja dimunculkan untuk membongkar dan melawan homogenisasi budaya dengan memunculkan konsep dan cara hidup berdampingan dan representasi sosio-kultural yang sama atau adil dari kultur yang berbeda 
dan masyarakat di dalam negara-bangsa (Jurnal Asian Ethnicity, Vol. 7 No. 2, Juni 2006).

Tesis homogenisasi budaya menyatakan bahwa globalisasi, kapitalisme, dan konsumerisme cepat atau lambat akan mendorong hilangnya keanekaragaman budaya. Tesis ini menekankan tentang kekhawatiran meningkatnya "kesamaan" budaya massa dan berasumsi mulai hilangnya otonomi budayabudaya lokal. Kerena semuanya direduksi dan terintegrasi ke dalam sistem budaya global. Penetrasi budaya global yang dominan direpresentasikan oleh budaya Barat dan Amerika ayang semakin kuat dan keras sering bergulirnya globalisasi. Di mana di sana ada standarisasi yang dibalut dengan idiologi liberalisme dan kapitalisme

Homogenisasi kultural memiliki kecenderungan sangat kuat akan mendorong hilangnya keragaman budaya, sekaligus sebaliknya menghapuskan otonomi dan identitas budaya lokal. Nilai, norma dan lembaga sosial dan kultural masyarakat -pelan tapi pasti- akan mengalami proses erosi yang terstruktur, sistematis dan massif yang kemudian berujung pada pelenyapan struktur budaya lokal.

Perlu diingat bahwa globalisasi, kapitalisme dan konsumerisme bukanlah agenda atau proyek global yang tanpa nilai dan kepentingan. Globalisasi, kapitalisme, dan konsumerisme adalah proyek global yang dirancang dan dijalankan secara matang, terstruktur dan sistematis oleh negara-negara industri maju (kapitalis) untuk menata sistem kehidupan global ini menjadi seragam sesuai dengan nilai, ideology dan kepentingan mereka. Konsekwensi dari rancangan global tersebut tentu saja akan berdampak pada hilangnya berbagai kearifan lokal dan beragaman budaya lokal. Budaya lokal "dipaksa" tunduk pada kemauan dan kepentingan global atau negaranegara industry maju. Ini mengingatkan nalar pikir saya pada pernyataan Anthony Gidden (2001:XVI) yang mengatakan, globalisasi telah merombak cara hidup kita besar-besaran. Ia bermula dari Barat, membawa jejak kuat kekuasaan politik dan ekonomi Amerika, serta mempunyai konsekwensi yang sangat tidak seimbang. Globalisasi juga melahirkan pola hubungan yang tidak seimbang dan sarat dominasi negara maju atas negara berkembang atau miskin.

Homogenisasi budaya yang dirancang dan disebarluaskan melalui globalisasi, kapitalisme, dan konsumerisme semakin merombak tata laku dan pola perilaku budaya masyarakat (lokal). Keseragaman juga telah menimbulkan kekacauan dan hilangnya identitas sosio-kultural di tingkat masyarakat. Identitas sosio-kultural masyarakat semakin tergerus seiring dengan kuatnya dan gencarnya penetrasi budaya global (Barat). Contoh yang paling sederhana dalam masalah perilaku dan budaya makan.masyarakat kita sudah gandrung dengan pola makan instan ala Barat (baca: Mcdonald, KFC, dll). Budaya serba instan juga merembet pada aspek kehidupan yang lain. Gaya hidup, norma, dan nilai, adat dan kebiasaan, keyakinan agama, pola kehidupan keluarga, cara produksi, dan konsumsi masyarakat pribumi rusak akibat penetrasi dan homogenisasi kultur Barat modern (Sztompka, 2004).

Dalam konteks global, modernisasi dan westernisasi yang usung oleh negara Barat dengan idiologi kapitalismenya telah melakukan penetrasi terhadap berbagai komoditas nilai, gaya hidup, cara berfikir, norma sosial ala budaya Barat. Semua itu terus mengusik keseharian masyarakat lokal. Bahkan masyarakat lokal tak sekedar mendapatkan penetrasi budaya, tapi lebih kejam dari itu adalah apa yang sebut Herbert Schiller $(1969,1985)$ sebagai Imperalisme Kultural. Menurut Schiller, industri media dan komunikasi global didominasi oleh perusahaanperusahaan yang dikendalikan oleh Amerika Serikat. Schiller menunjukkan bahwa jaringan TV AS, yang menghubungkan para subkontraktor pertahanan atau militer dengan pemerintah federal. Media massa masuk ke dalam jaringan sistem kapitalis dengan cara menyediakan dukungan idologis untuk kapitalisme, khususnya untuk perusahaan transnasional. 


\section{Lenyapnya Identitas Budaya}

Penetrasi budaya Barat yang terlalu dipaksakan juga sangat berpotensi pada munculnya konflik dan kekerasan. Budaya Barat yang mengangung-agung nilai-nilai kebebasan yang disebarkan kepada masyarakat kita telah menimbulkan dampak negatif. Misalnya disintegrasi sosial-politik, leyapnya stabilitas sosial dalam menghadapi realitas kehidupan yang semakin sulit sehingga mudah mengamuk, melakukan berbagai tindak kekerasan dan anarkhi, merosotnya penghargaan dan kepatuhan pada hukum, etika, moral dan kesantunan sosial. Kesemuanya itu salah satunya bersumber dari masalah etnis dan agama. Sebut saja misalnya kekerasan di Aceh, Papua, dan berbagai daerah konflik lainnya di Indonesia.

Dengan kata lain, Identitas budaya lokal kita semakin tereduksi dengan adanya "penjajahan budaya Barat". Budaya gotong royong, sopan-santun, tradisi "pelagandong" di Ambon misalnya, tradisi-tradisi serta kearifan lokal lainnya, semakin tercerabut dari akarnya, dan digantikan dengan budaya Barat yang sarat dengan Individualisme, Instan, kekerasan, dan anarkhi, yang semua itu akarnya dirancang oleh idiologi liberalisme-kapitalisme dan konsumerisme dan dibawa oleh globalisasi. Globalisasi menjadi instrument akselerator dalam menyebarkan budaya global atau Barat. Akibatnya masyarakat kita mengalami disorientasi dan dislokasi yang akan mengancam kohesifitas dan solidaritas sosial masyarakat.

Ulf Hannerz mengatakan bahwa homogenisasi cultural, di mana kultur Barat akan mendominasi seluruh dunia. Atau dengan istilah lain, "Westernisasi" atau yang lebih riil "Amerikanisasi”, akan menyebabkan keunikan kultur lokal (pribumi) akan lenyap karena dominasi kultur Barat (Sztompka, 2004). Dalam pikiran yang lain yang lebih idiologis, praktek homogenisasi yang bawa oleh kapitalisme, modernisasi, dan konsumerisme, menyatakan bahwa semua itu telag mengakibatkan keluhan bahwa berbagai sistem kultur dunia yang menonjol telah mengalami kemrosotan karena proses "penyelarasan cultural" terjadi tanpa keteladan historis (Hamelink, 1983 dalam Sztompka, 2004)

Disorientasi, dislokasi atau krisis sosialbudaya dikalangan msyarakat kita semakin merebak seiring dengan kian meningkatnya penetrasi dan ekspansi dan homogenisasi budaya Barat tersebut- khususnya Amerika Serikatsebagai akibat proses globalisasi yang terus tidak terbenung. "Gaya hidup" baru ala Barat yang penuh dengan nilai kebebasan tidak selalui sesuai dan kondusif dengan kehidupan sosialbudaya masyarakat dan bangsa. Sebut saja misalnya merebaknya budaya McDonald yang menginspirasi lahirnya budaya serba instan, meluasnya budaya telenovela, yang menyebarkan permisivisme, kekerasan, dan hedonism; mewabahnya MTVisasi, Valentin's day, dan kini juga berkembang pub night di kalangan remaja. Meminjam ungkapan Edward Said, gejala ini tidak lain daripada "cultural imperalisme" baru, yang menggantikan imperalisme klasik yang terkandung dalam “orientalisme"(Mahfud, 2005).

Dari berbagai kecenderungan ini, maka orang bisa menyaksikan kemunculan kultur hybrid, budaya gado-gado tanpa identitas, di Indonesia dewasa ini. Pada satu segi, kemunculan budaya hybrid (campuran) nampaknya tidak terelakkan, khususnya karena globalisasi yang semakin sulit dihindari. Akan tetapi, di segi lain, budaya hybrid (campuran) apalagi yang bersumber dari dan didominasi budaya luar, karena dominasi dan hegemoni politik, ekonomi, dan informasi mereka-dapat mengakibatkan krisis budaya nasional dan lokal lebih lanjut. Tidak hanya itu, budaya hybrid dapat mengakibatkan lenyapnya identitas kultural nasional dan lokal padahal identitas nasional dan lokal tersebut sangat mutlak bagi terwujudnya integrasi sosial, kultural dan politik masyarakat dan negara-bangsa Indonesia (Mahfud, 2005)

Globalisasi budaya ditunjukkan dengan kemajuan menuju keseragaman. Media massa, misalnya, terutama TV, mengubah dunia menjadi sebuah "dusun global" (global village) (McLuhan (1964). Informasi dan dan gambar peristiwa yang terjadi di tempat yang sangat 
jauh dapat ditonton jutaan orang pada waktu bersamaan. Suguhan pengalan cultural yang sama itu (Olimpiade, konser rock, epak bola, dan sebagainya) menyatukan selera, persepsi, dan pilihan mereka. Aliran budaya konsumerisme merebak dengan cepat. Aliran barang konsumsi seperti Coca Cola, menjangkau seluruh penjuru dunia (Sztompka, 2004).

Globalisasi dan modernisasi inilah mendapat kritik tajam dari kalangan postmodernisme. Kalangan Postmo mengatakan, modernisasi -berikut perangkat-perangkat modernnya- telah gagal menciptkan kehidupan masyarakat yang lebih baik; lebih sejahtera, berkeadilan, bermartabat, dan berkemanusian. Di bidang budaya, modernisasi dan homogenisasi kultural telah membawa masyarakat (lokal) kehilangan identitas kulturalnya.

Globalisasi dan homogenisasi budaya merupakan kampanye besar-besaran yang dilakukan oleh negara-negara industri maju atau kapitalis Barat untuk menyakinkan seluruh dunia bahwa pilihan terakhir dan terbaik bagi masa depan semua Negara di dunia adalah tuntuk pada hukum-hukum ekonomi pasar bebas yang kapitalistik dalam kerangka sistem politik yang "demokratis" ala Barat. Homogenisasi kultural selalu hadir dalam wajah-wajah globalisasi ekonomi, politik, sosial dan budaya. Proses dan praktek homogenisasi kultural tersebut dilakukan melalui cara kekerasan (coersif) dan soft-knowladge atau hegemoni. Dan inilah gaya imperalisme budaya di abad modern.

Karena itu, korbannya (baca: masyarakat berserta identitas sosio-kulturalnya) ada yang langsung tak berdaya menghadapi "penjajahan budaya" Barat tersebut. Kita bisa melihat masyarakat kita yang sangat gandrung pada mode pakaian (fashion), perilaku dan pola makan, dan budaya ala Barat lainnya yang semua itu bisa diakses dalam hitungan detik, Modal sosial dan budaya "genuine" yang selama ini telah berjalan bertahun-tahun, turuntemurun, dan memberikan kontribusi positif pada ikatan sosial, kolektivisme, dan solidaritas sosial, semakin terkikis dan digantikan idiologi dan budaya individualism.

Gustavo Esteva Madhu Suri Prakash memberikan analisis dan kritik tajam atas tiga pilar yang sekaligus "mitos" proyek globalisasi; Pertama, Konsep otoritas dan otonomi "pribadi perorangan (individual self), Kedua, konsep universalitas "hak azazi manusia" (human rights); dan Ketiga, konsep kemajuan "pembangunan" (development). Para pengajur proyek globalisasi yakin bahwa tiga mitos tersebut yang akan menjadi "masa depan dunia" dan merupakan suatu keniscayaan, sehingga mereka yang menolaknya akan tergilas habis oleh roda sejarah (Demokrasi Radikal: Otonomi Lokal, Bukan Globalisasi, Jurnal Ilmu Sosial Transformatif "WACANA" No. II, 1999.).

Globalisasi yang di dalamnya ada modernisasi yang -salah satunya- diwujudkan dalam praktek homogenisasi kultural, secara nyata telah menimbulkan kecemasan, ketakutaan, eksploitasi, kemiskinan massal, menumpuknya keluhan dan ketidakpuasan, dan dehumanisasi (harga diri sebagai manusia yang berada semakin terdegradasi secara massif, identitas ke-manusia-annya semakin menghilang). Tidak hanya nilai kemanusiannya saja yang menghilang, tapi juga identitas kultural lainnya. Jati diri masyarakat yang original yang penuh dengan kebersamaan dan semakin kabur dan bahkan tereduksi oleh budaya global yang berwatak materialistik.

Dalam konteks msyarakat Indonesia, globalisasi telah melahirkan kecenderungan baru, yakni munculnya kultural hybrid, budaya gado-gado, budaya tanpa identitas. Warga masyarakat atau komunitas masyarakat Indonesia mengakomodasi dan mengadopsi nilai dan budaya yang beragam dari berbagai dunia. Sementara budaya dan tradisi lokal Indonesia sendiri semakin termarjinalisasi. Contoh yang paling konkrit adalah fenomena anak-anak kita yang lebih suka permainan Gadget daripada permainan tradisional, seperti Petak Umpet, Bola Bekel, gundu, Lompat Tali, dan sebagainya. Selain itu, munculnya gaya hidup dan pola makan anak-anak zaman sekarang, yakni muncul komunitas pemuda- 
pemudi menyuka makanan China, makanan jepang, makanan AS,d dan sebagainya, termasuk munculnya anak-anak kita yang lebih suka makan di restoran-restoran asing.

\section{Ancaman bagi Masyarakat Multikultural Indonesia}

Gerak globalisasi akan mengarah pada upaya penyeragaman budaya. Idiologi penyeragaman ini tentu saja akan mengancam eksistensi masyarakat multikultural. Masyarakat yang majemuk yang di dalamnya terdapat pengakuan, penghormatan, saling bekerjasama, toleransi, dalam membangun masyarakat yang harmonis, meskinpun berbeda-beda. Antar entitas budaya bisa hidup berdampingan (coexistency), tidak ada konflik, perselisihan, dan perpecahan. Perbedaan dan beragamnya budaya, masyarakat mampu mengelola perbedaan dengan baik bagaikan sebuah pelangi; meskipun berwarna-warni, namun bisa menunjukkan keharmonisan sosial yang dipandang secara indah.

Berbeda dengan konsep pluralism yang lebih menekankan keberadaan masing-masing kebudayaan yang beragam. Masyarakat majemuk adalah sebuah keniscayaan sosial, yang pada prinsipnya lebih menekankan relasi atau pola hubungan antara ragam kebudayaan yang berbeda. Dengan kata lain, keberadaan suatu kebudayaan harus mempertimbangkan keberadaan kebudayan yang lain. Dari sinilah lahir gagasan tentang kesetaraan, toleransi, saling menghormati dan menghargai (Fedyani,2006)

Masyarakat multikultural adalah suatu masyarakat yang terdiri dari beberapa macam kumunitas budaya dengan segala kelebihannya, dengan sedikit perbedaan konsepsi mengenai dunia, suatu sistem arti, nilai, bentuk organisasi sosial, sejarah, adat serta kebiasaan (" $A$ Multicultural society, then is one that includes several cultural communities with their overlapping but none the less distinc conception of the world, system of [meaning, values, forms of social organizations, historis, customs and practices"; Parekh, 1997)
Masyarakat multikultural lebih menekankan pada kesederajatan dan kesetaraan budaya-budaya lokal tanpa mengabaikan hakhak dan eksistensi budaya yang lain. Dalam faham ini terkandung aspek pengakuan dan penghormatan yang tulus akan martabat manusia yang hidup dalam komunitas dengan kebudayaannya masing-masng yang unik (Mahfud, 2006:XIX-XX). Multikulturalisme mengandung gagasan/ide-ide, cara pandang, kebijakan, penyikapan, dan tindakan yang dilakukan oleh suatu masyarakat atau negara yang memiiki keberagaman atau kemajemukan, baik dari segi etinis, budaya, agama, dan sebagainya. Namun demikian, dibalik perebdaan tersebut terkandung cita-cita kolektif, yakni bagaimana membangun dan mengembangkan semangat kebangsaan dan nasionalisme yang sama dan mempunyai kebanggaan untuk saling mempertahankan kemajemukkan sehingga keharmonisan sosial tetap terjaga secara berkesinambungan.

Karena itu, menurut Sosiolog Universitas Airlangga, Daniel Sparinga Surabaya, globalisasi akan menjadi ujian penting bagi eksistensi masyarakat multikultural, yakni masyarakat dengan berbagai latar sosial-budaya yang beragam dapat hidup berdampingan secara damai dalam prinsip co-existence yang ditandai oleh kesadaran dan kesediaan kolektif untuk saling menghormati dan menghargai budaya lain. Dengan kata lain, kelompok etnik dan budaya yang berbeda tersebut, di satu pihak memiliki kemampuan untuk memelihara dan mengembangkan identitas kelompoknya secara otonom, dan di pihak lain mereka mampu berinteraksi secara bebas dan intensif dalam ruang bersama yang ditandai oleh kesediaan untuk saling menerima keragaman dan toleransi (mengakui dan menghormati perbedaan). Setiap ragam budaya: kelompok-kelompok etnik Pidie, Mandailing, Minang, Betawi, Sunda, Jawa, Cina, Bali, Manggarai, Ambon, Manado, Serui, yang beragama Islam, Hindu, Khong $\mathrm{Hu} \mathrm{Chu}$, Budha, Kristen, Khatolik, atau yang beraliran kepercayaan dan ragam budaya lainnya, itu semua mampu hidup berdampingan dalam sebuah habitat sosial yang di satu pihak 
memberi tempat bagi terpeliharanya identitas lokal dan kepercayaan partikularnya masingmasing, dan di pihak lain memberi kesempatan bagi sebuah proses terjadinya integrasi sosial, politik, budaya, dan ekonomi baik di tingkat nasional maupun yang ada pada level global (www.komunitasdemokrasi.or.id).

Keragaman budaya tersebut harus dihadirkan sebagai bentuk ekspresi eksotisme komunitas etnik yang lokal dan partikular, sebagai antitesa dari rasionalitas dan modernitas budaya global yang memaksakan keseragaman. Karena itu, dalam konteks global, masyarakat multikultaral harus cermat untuk memperhatikan apa yang disebut sebagai perangkap budaya globalisasi. Globalisasi yang sedang berlangsung dapat membuat masyarakat menjadi terasing pada dua hal sekaligus: terasing dari habitat kita sendiri dan dari dunia yang mengelilingi kita. Perangkap ini dapat membuat kita terkecoh karena multikulturalisme yang dalam asasnya tak berbeda dengan pendekatan Asimilasi. Namun demikian, proses asimilasi budaya ataupun akulturasi budaya justru mengakibatkan terjadinya proses dislokasi, disorientasi, disafiliasi, dan disintegrasi. Ini tak lepas dari idiologi dan watak global yang berusaha untuk melakukan homogenisasi budaya.

Singkatnya, masyarakat multukultural, termasuk masyarakat Indonesia akan menghadapi ancaman yang cukup serius dari arus globalisasi dan modernisasi, yakni; Pertama, menjadikan yang beragam menjadi seragam. Keberadaan entitas dan komunitas budaya yang beragam dan telah hidup berdampingan (co-existency) cukup lama, dipaksa berintegrasi masuk ke dalam sistem budaya global yang seragam. Kedua, keseragaman atau homogenisasi budaya akan berpotensi merusak dan menghancurkan masing-masing identitas budaya. Konflik dan perpecahan bukan tidak mungkin akan terjadi jika keseragaman terlalu dipaksakan. Ketiga, ancaman meleburnya budaya lokal yang unik masuk ke dalam budaya global yang bersifat materialistik. Sehingga pelan tapi pasti, entitas budaya budaya lokal akan semakin terkikis, yang muncul adalah budaya dominan, yakni budaya global atau lebih diasosiasikan dengan budaya Barat.

Menurut Bhikhu Parekh, seorang tokoh multikulturalis dan pakar teori politik yang namanya dikenal luas secara internasional di dunia ilmu-ilmu sosial, dalam bukunya yang terbaru berjudul A New Politics of Identity: Political Principles for an Interdependent World (2008) mengatakan bahwa salah satu tantangan masyarakat multicultural dalam kehidupan global adalalah bagaimana membangun prinsip politis mendasar yang bisa memberi arah bagi sebuah dunia global. Prinsip dasar yang dimaksud Parekh adalah sebuah politik identitas yang baru. Globalisasi memang menantang identitas-identitas tradisional seperti identitas suku, budaya, agama atau bahkan identitas nasional. Tantangan itu terjadi karena globalisasi tampak menghapus batas-batas suku, budaya, agama, negara dan batas-batas sosial lain seperti gender atau orientasi seksual. Di hadapan globalisasi, batas-batas tradisional yang memisahkan antar suku, budaya, agama dan negara tampak menghilang. Menghadapi tantangan global seperti ini, suku, budaya, agama, negara serta batas sosial yang lain, tidak ada pilihan lain kecuali beroperasi di dalam sebuah konteks historis yang baru, mengikuti semua perubahan dan mengambil langkah pemahaman baru termasuk pemahaman atas krisis identitas tradisional yang lama melekat dalam diri anggota masyarakat.

Identitas merupakan salah satu tema sentral di hadapan globalisasi. Sentralnya tema ini bisa dipahami karena globalisasi membawa efek historis baru yang tak bisa dipungkiri yakni sebuah masyarakat global atau lebih khusus lagi sebuah masyarakat multikultural seperti Indonesia. Identitas memberi rasa keberakahan dan juga rasa memiliki. Di dalam buku barunya tersebut, Bhiku Parekh mencoba menata ulang bagaimana identitas-identitas tradisional bisa ditata dalam abad global yang kita hadapi. Bagi Parekh, di tengah sebuah dunia global, identitasidentitas tradisional perlu diintegrasikan ke dalam sebuah identitas manusiawi yang universal di mana orang dan masyarakat bisa 
berakar dalam tradisi tertentu tetapi juga terbuka kepada tradisi lain atau menjadi anggota masyarakat tertentu tetapi juga merasa menjadi bagian dari umat manusia sebagai satu komunitas global.

Dalam konteks Indonesia, globalisasi pada saat yang sama juga dapat memberi peluang hadirnya kesadaran-kesadaran baru dari individu dan kelompok masyarakat untuk kembali pada identitas awalnya, yakni Identitas masyarakat Indonesia yang berbasis pada budaya Indonesia. Munculnya ekspresi-ekspresi budaya dari berbagai daerah dalam sebuah acara formal dan nonformal kenegaraan atau dalam sebuah eksebisi budaya daerah. Selain itu, munculnya gerakan sosio-kultural dari sekelompok masyarakat untuk kembali mencintai produk-produk dalam negeri atau anak negeri, dan berbagai ekspresi budaya lainnya yang saat ini sudah semakin menggejala di tengah derasnya arus globalsiasi, termasuk globalsiasi budaya. Semua itu menunjukkan bahwa, masyarakat multikultural Indonesia memiliki potensi dan daya tahan atau imunitas yang cukup besar untuk menghadapi arus globalsiasi atau homogenisasi budaya yang bersifat kolonialistik. Daya imunitas budaya ini dapat tumbuhkembangkan, baik scara struktural (baca: negara) maupun kultural (baca: masyarakat) secara konsisten dan berkesinambunga, dengan prinsip mampu berinteraksi dengan dunia global dengan tanpa melunturkan nilai dan identitas budaya lokal..

Argumen Parekh memang tampak liberal tetapi pada saat yang sama argumennya ini menantang ancaman-ancaman global yang tengah kita hadapi seperti fundamentalisme religius, terorisme dan perang melawan teror. Politik identitas memang sejauh ini dipahami dan diarahkan dalam artian identitas personal dan identitas kolektif seperti identitas yang dibangun atas dasar gender, orientasi seksual, suku, agama dan bangsa. Tentu saja identitas seperti ini penting tetapi pada saat yang sama sebuah afirmasi atas identitas manusiawi yang universal sangat krusial di mana identitas khusus bisa ditempatkan dalam bingkai identitas manusia yang universal sebagai sebuah politik identitas yang baru.

Membaca argumen Parekh, orang akan segera bertanya tentang dasar dan mesin apa yang menggerakkan politik identitas baru ini. Sambil membaharui sejumlah jawaban atas pertanyaan seperti itu, menurut Parekh, politik identitas baru ini perlu didasari oleh etika dan tanggung jawab global dan disemangati oleh roh solidaritas antar manusia. Parekh tidak begitu saja menutup mata atas kenyataan perbedaan politis, budaya dan sosial antar masyarakat atau komunitas. Tetapi ia memahami atau lebih tepat memberi definisi baru atas politik perbedaan. Baginya, perbedaan adalah sumber-sumber energi moral yang kaya yang perlu diberi struktur baru dalam terang harmoni identitas universal. Perbedaan dan nilai universal karena itu bukanlah dua hal yang bertentangan tetapi saling melengkapi. Di sini, partikularitas atau perbedaan dihargai, tetapi bukan partikularisme yang memandang perbedaan sebagai horison yang absolut dalam pemahaman atas identitas dan pencapaian nilai universal sebagai sebuah mimpi utopia; hal yang universal dijunjung, tetapi bukan universalisme yang memandang perbedaan-perbedaan sebagai penjara-penjara yang menyengsarakan hidup bersama dan komunitas umat manusia

\section{Peluang bagi Masyarakat Multikultaral Indonesia}

Globalisasi, yang di dalamnya ada modernisasi dan dan westernisasi yang begitu massif dan invansif ternyata mengakibatkan perubahan sosial yang begitu besar dalam masyarakat Negara non Barat atau Asia, termasuk Indonesia. Perubahan tersebut tidak saja pada tataran struktural, namun juga pada tataran kultural. Struktur sosial, politik, ekonomi dan budaya masyarakat mengalami perubahan yang dratis, dimana struktur-struktur tersebut dipaksa untuk menyesuaikan diri dengan semangat dan prinsip yang terkandung dalam idiologi modernisasi dan westernisasi yang berwatak liberalistik. Pada saat yang bersamaan, kondisi ini yang kemudian memaksa masyarakat Asia atau Negara -Negara non Barat untuk 
menanggalkan sistem nilai-nilai, norma sosial, ekonomi, politik dan budayanya. Dengan kata lain, nilai-nilai luhur masyarakat Asia yang diwujudkan dalam sebuah identitas kultural atau agama, semakin tercerabut dari akarnya dan digantikan dangan nilai dan norma kehidupan ala Barat.

Dalam konteks pergaulan global, menjadi kesadaran bersama bahwa perubahan bukan untuk dihindari tapi untuk dihadapi. Pada titik ini, bagaimana masyarakat multikulral siap dan mampu menghadapi konsekwensi dari sebuah perubahan global tersebut. Sebagai bagian dari budaya dan kehidupan global, tentu saja masyarakat multikultural tidak perlu hanyut pada pengaruh global yang berkencenderungan pada upaya penyeragaman budaya. Bagaimana masyarakat multicultural mampu menjaga dan memelihara multikulturalisme-nya dalam masyarakat global?.

Globalisasi bagi masyarakat multukultural Indonesia justru harus dimanfaatkan sebagai peluang positif untuk membangun kesadaran baru yang lebih imune, yakni memperkuat kolektivitas dalam perbedaan. Karena salah satu dampak dan sekaligus ancaman dari globalisasi adalah munculnya gesekan dan konflik sosial, politik, budaya dan ekonomi. Di tengah persaingan global yang semakin ketat, baik individu maupun kelompok/negara berusaha untuk menancapkan perngaruhnya (sosial, politik, ekonom, budaya, militer) ke berbagai negara, baik dengan cara halus (softskill) maupun cara paksaan atau kekerasan (hardskill).

Nils A Shapio, Editor Gallery Magazine, berpendapat, ada enam kiat sukses menghadapi tantangan globalisasi; Pertama, membuat perencanaan yang cermat. Di tengah kehidupan yang semakin kompetitif, perencanaan yang cermat merupakan sebuah keniscayaa. Dengan perencanaan, keberhasilan menjadi lebih mudah. Kedua, latihan dan pengalaman; latihan dan pengalaman akan meningkatkan profesionalisme seseorang dalam berbagai bidang kehidupan. Ketiga, bersedia belajar dari orang lain; sumber belajar menurut teori pendidikan, tidaklah sebatas pada guru dalam antian pengajaran formal di sekolah. Kita dapat pula belajar dari banyak buku. Karena buku adalah representasi pengalaman orang lain.

Keempat, terbuka dan siap bersedia bekerjasama; sebagai masyarakat multicultural, sikap terbuka dalam bekerjasama akan meningkat perluang dan kesempatan untuk mendapatkan keuntungan. "rejeki" orang bisa berasal dari proses pergaulan, interaksi, dan kerjasama. Dengan bekerjasama, individu atau kelompok bisa saling berkontribusu. Sikap eksklusif jsutru akan semakin mengasingkan entitas budaya dalam masyarakat multicultural. Kelima, tabah menghadapi kekecewaan dan kemunduran; di tengah kompetisi yang semakin ketat, kegagalan bukan dijadikan sebagai "aib" yang membuat frustrasi dan merasa minder. Kegagalan dapat dijadikan sebagai pelecut untuk melakukan sesuatu yang lebih baik. Kegagalan bukanlah hal yang negatif bila dihadapi secara cerdas. Kata pepatah; kegagalan adalah kesuskesan yang tertunda.

Dalam konteks persaingan global, sikap optimis harus terus ditumbuh-kembangkan sehingga kita akan selalu memiliki masa depan. Dalam konteks masyarakat multicultural, indvidu atau kelompok yang beragam dituntut untuk saling saling sapa, interaksi, bekerjsama, sehingga masing-masing tidak merasa terasing. Masing-masing entitas budaya optimis mampu menjaga keharmonisan dan kohesi sosialnya ntuk mencapai cita-cita masyarakat multikultural yang benar-benar membumi.

Keenam, bersikap jujur (ability to be honest); tanpa kejujuran, keberhasilan yang diraih bersifat semu dan sementara. Jika kepalsuan sudah terbongkar, runtuhlah seluruh bangunan usaha susah payah yang telah dibangun (Mahfud: 2006:112-116).

\section{PENUTUP}

Globalisasi telah melahirkan aspek peluang dan tantangan atau ancaman, dampak positif dan negatif, bagi kehidupan masyarakat baik dalam tingkat tingkat global maupun lokal. Dalam konteks ini, masyarakat multikultural langsung maupun tidak langsung akan merasakan dampak dari globalisasi. Politik multikulturalisme akan berpotensi menghadapi 
ancaman dan tantangan yang sangat serius, salah satu idiologi globalisasi adalah homogenisasi budaya. Dan idiologi ini sangat jelas bertentangan dengan idiologi dan spirit multukulturalisme.

Karena itu, masyarakat multicultural dituntut untuk lebih kritis dan cerdas dalam menghadapi berbagai dampak subversif dan destruktif dari globalisasi yang akan merusak tatanan sosio-kultural masyarakat yang beragam. Keragaman bukanlah untuk disamakan, tapi dibiarkan hidup secara alamiah untuk bisa hidup berdampingan (co-existency) dalam perbedaan. Perbedaan dan keragaman harus dijaga, dipelihara dan dikembangkan sebagai kekuatan yang positif dalam membangun keharmonisan sosial sehingga kehidupan ini bagaikan pelangi yang begitu indah dan eksotik serta menarik untuk menjadi tontotan publik.

Bagi masyarakat multukultural atau multikulturalisme bisa dijadikan sebagai peluang positif untuk merekatkan nilai, normanorma sosial kolektif dalam perbedaan dan keberagaman. Masyarakat multkultural bisa bersikap lebih kritis, dewasa, dan selektif dalam memilih dan memilah nilai, norma-norma yang diproduksi oleh globalisasi (baca: modernisasi dan kapitalisme) mana yang bisa memberi kontribusi postif bagi pengembangkan masyarakat multikulral yang lebih baik dan matang.

\section{DAFTAR RUJUKAN}

Faqih, Mansour., (2001), Sesat Pikir Teori Pembangunan dan Globalisasi, Insist Press Bekerjasama dengan Pustaka Pelajar, Yogyakarta.

Gustavo Esteva \& Madhu Suri Prakash., (1999), Demokrasi Radikal: Otonomi Lokal, Bukan Globalisasi, dalam Jurnal Ilmu Sosial Transformatif "WACANA" No. II, Tahun 1999, Yogyakarta.
Giddens, Anthony., (2001), Runway World; Bagaimana Globalisasi Merombak Kehidupan Kita?, PT. Gramedia Pustaka Utama, Jakarta

Parekh, B., (1997)., National Culture and Multiculturalism. In Kenneth Thompson (ed) Media and Cultural Regualtion, London-Thousand Oaks, Calif: Sage Publication in Association with the Open University;

Polanyi, Karl., (2003), Transformasi Besar; Asal-Usul Politik dan Ekonomi Zaman Sekarang, terj. M. Taufik Rahman, Pustaka Pelajar, Yogyakarta.

Mahfud, Choirul,. (2008), Pendidikan Multikulral, Pustaka Pelajar, Yogyakarta.

Sztompka, Piotr., (2004), Sosiologi Perubahan Sosial, Prenada Media Group, Jakarta.

Yang Hoong, Chang., (2006), Assimilation, Multiculturalism, Hybridity: The Dillemmas of the Etnic Chinese in Post-Suharto Indonesia, Junal Asian Ethnicity, Volume 7, No. 2, Juni 2006, Taylor \& France Group, Carfax Pulishing, France.

Saifudin A.F., (2006)., Membumikan Multikulturalism di Indonesia, Jurnal Antropologi Sosial-Budaya "ETNOVISI", Vol. II, No. 1, April 2006, UI Jakarta.

\section{Opini Media Daring}

An Nawie, Murdianto., Homogenisasi Budaya dan Siasat Hibriditas, Opini Geotimes.co.id, 27 Januari 2018), dapat diakses di https://geotimes.co.id/opini/homogenis asi-budaya-dan-siasat-hibriditas/

Sparinga, Daniel., Multikulturalisme Indonesia: Jawaban terhadap Kemajemukan dalam

http://www.komunitasdemokrasi.or.id) 